Fred Carlo Andersen

Avdeling for lcererutdanning

Høgskolen i Østfold

E-post: fred.c.andersen@hiof.no

\title{
Rektorutdanningens potensial i en flerkulturell kontekst
}

\section{Sammendrag}

I et samfunnsperspektiv er det nødvendig å gi økt oppmerksomhet til spørsmål som berører språklig og kulturelt mangfold, der skoleledere har et scrskilt ansvar for å følge opp den nasjonale skolepolitikken på dette området. Utdanning av skoleledere, slik som rektorutdanningen som har vart tilbudt siden 2009, har som formål å utvikle skoleledernes kompetanse på mange områder. Evaluereringer av dette utdanningstilbudet har vist at deltakerne oppfatter utdanningens pedagogiske kvalitet og praksisrelevans som høy. Vi vet imidlertid mindre om hvordan rektorutdanningen bidrar til bedre ledelse i en flerkulturell skole. Formålet med denne artikkelen er å undersøke på hvilken måte rektorutdanningen har potensial til å utvikle ledere for en inkluderende, likeverdig og rettferdig flerkulturell skole. Analysen er bygd på intervjuer med skoleledere som har deltatt i rektorutdanningen i perioden 2013-2015. Resultatene, som er drøftet i lys av et kritisk perspektiv på ledelse, viser at temaer knyttet til språklig og kulturelt mangfold i skolen ikke var berørt i scerlig grad. Analysen indikerer også at rektorutdanningen ikke har bidratt til økt kompetanse i å håndtere utfordringer knyttet til språklig og kulturelt mangfold. Ett unntak gjelder imidlertid utdanningsrettslige emner. Det er mye som tyder på at rektorutdanningen har et stort potensial når det gjelder å bidra til å utvikle skolelederes kompetanse for en språklig og kulturelt mangfoldig hverdag.

Nøkkelord: skolelederes kompetanse, rektorutdanning, språklig og kulturelt mangfold, kritisk teori

\section{Abstract}

From a society perspective it is necessary to pay increased attention to questions concerning linguistic and cultural diversity, where school leaders have a particular responsibility to follow up the national school policy within this area. The national school leadership program in Norway, which started in 2009, aims at developing school leaders in many areas. Evaluations have shown that the participants consider the pedagogical quality and the relevance for their praxis as very high. However, we do not know how the program 
contributes to increased leadership quality in linguistically and culturally diverse schools. This article aims at investigating the program's potential to develop leaders for a more inclusive, equity oriented multicultural school. The analysis builds on reflection notes and interviews with school leaders who have participated in the program between 2013 and 2015. The results discussed in the light of critical perspectives on school leadership, show that themes related to linguistic and cultural diversity are rare. Except for juridical subjects, the analyses indicate that the program has not contributed to increased competence regarding leadership in a linguistically and culturally diverse school context. However, the program has a great potential to develop school leaders for this context.

Kewwords: school leaders' competence, school leadership preparation program, linguistic and cultural diversity, critical theory

\section{Innledning}

Formålet med denne artikkelen er å undersøke rektorutdanningens potensial til å utvikle ledere som fremmer et rettferdig, inkluderende og likeverdig opplæringstilbud i en språklig og kulturelt mangfoldig skolekontekst. Den globale utviklingen, med mennesker på flukt fra krig og katastrofer på søken etter trygghet og et bedre liv, har nasjonale implikasjoner. I et samfunnsperspektiv er det nødvendig å gi økt oppmerksomhet til spørsmål som berører språklig og kulturelt mangfold, der skoleledere har et særskilt ansvar for å følge opp den nasjonale utdanningspolitikken på dette området. En viktig målsetting for norsk utdanningspolitikk er å styrke kunnskapsgrunnlaget omkring minoritetsspråklige elevers læringsmiljø, hvor skoleeiere og skoleledere har en viktig rolle i det systematiske og langsiktige arbeidet (Barne-, likestillings- og inkluderingsdepartementet, 2012). Vurderingen av ledelsens betydning for at skoler oppnår bedre elevresultater, og innvirkningen på læringsmiljø, får stadig større oppmerksomhet (OECD, 2008). Det norske skolesystemet er dessuten mål- og resultatorientert, og skoleledere blir i økende grad holdt ansvarlige for skolens utvikling og elevenes resultater (Langfeldt, Elstad, \& Hopmann, 2008; Møller, 2009). Opprettelsen av den nasjonale rektorutdanningen i 2009 er en videreføring av sentrale elementer i Kunnskapsløftet, som blant annet understreker betydningen av myndiggjøring av profesjonen, ansvarliggjøring og kunnskapsbasert yrkesutøvelse for utvikling av kvalitet i skolen (Kunnskapsdepartementet, 2004). Rektor tillegges en viktig funksjon blant annet ved oppfølgingen av lærerne gjennom å styrke deres motivasjon og å legge til rette for gode arbeidsforhold, som igjen kan få stor betydning for elevenes læring (Robinson, Lloyd \& Rowe, 2008). En viktig målsetting for den nasjonale rektorutdanningen er nettopp å styrke kompetansen til rektorer og andre skoleledere, slik at de kan imøtekomme 
disse forventningene. Rektorutdanningen skal gi kompetanse og redskaper til å løse de viktigste utfordringene som en rektor og skoleleder vil stå overfor (Kunnskapsdepartementet, 2012).

Forskning på skoleledelse understreker at norsk skole står overfor sentrale utfordringer når det gjelder både kunnskapsutvikling og likeverd (Tolo \& Lillejord, 2006). Det stilles derfor forventninger til skoleledere om at de skal være i stand til å håndtere utfordringer knyttet til en språklig og kulturelt mangfoldig elevsammensetning (Kunnskapsdepartementet, 2007). Utfordringene kan knyttes til elevenes skolebakgrunn, familiens bakgrunn, med ulike erfaringer med hvordan det norske samfunnet fungerer, forskjellige førstespråk og varierende kompetanse i norsk språk (Andersen, 2012; Vedøy, 2008). Skolen spiller også en viktig rolle når det gjelder å bygge identitet og fellesskap i befolkningen. Temaer som er foreslått prioritert i fagfornyelsen i fremtidens skole, er demokrati og medborgerskap, som blant annet omfatter samhandling i et flerkulturelt samfunn (Kunnskapsdepartementet, 2016). Skoleledernes rolle har dermed stor betydning, utover det å bidra til gode læringsresultater for elevene. Denne artikkelen har som formål å bidra med kunnskap om rektorutdanningens potensial til å utvikle ledere for en rettferdig, inkluderende og likeverdig flerkulturell skole.

\section{Forskning på skolelederopplæringsprogram}

Internasjonalt er det en økende erkjennelse av skolelederes betydning for elevenes læring (Bush, Kiggundu \& Moorosi, 2012; Robinson et al., 2008). Forskning på skolelederopplæringsprogrammer er følgelig økende (Murphy \& Vriesenga, 2004).

Det er imidlertid liten grad av enighet knyttet til hvilke faktorer som skal vektlegges i opplæringsprogrammer for skoleledere (Boske, 2011; Bush et al., 2012; Capper, Theoharis \& Sebastian, 2006; Murphy \& Vriesenga, 2004). Dette kan skyldes at teoritilfanget om ledelse er svært rikholdig, og for mangfoldig til at det kan rammes inn på en enkel måte (Møller, 2004). Til tross for en tendens til større tilgang på forskning på skolelederopplæringsprogrammer viser en litteraturgjennomgang (Murphy \& Vriesenga, 2004) at det er behov for ytterligere empirisk og teoretisk forskning på dette området. Capper et al. (2006) har i en omfattende litteraturgjennomgang fra en amerikansk kontekst utviklet et teoretisk rammeverk knyttet til ledelse for rettferdighet, likeverd og inkludering. Formålet med deres studie var å foreslå rammeverket som en guide til å utvikle et opplæringsprogram for skoleledere. De peker blant annet på betydningen av at opplæringsprogrammet har som målsetting å utvikle skoleledernes kritiske bevissthet, kunnskap om hvordan maktrelasjoner kan virke undertrykkende på utsatte grupper og enkeltelever, og praktiske ferdigheter knyttet til å håndtere og legge til rette for at alle elever får et rettferdig opplæringstilbud. 
Den statlige rektorutbildningen i Sverige ble etablert allerede i 1976, og har vært gjennom flere evalueringer og revisjoner. Programmet, slik vi kjenner det i dag, ble etablert i 2007. Lahdenperä (2015) påpeker at den ikke inneholder spesifikke mål med tilknytning til den "multietniska och mångkulturella verklighet som många rektorer möter i sin vardag” (ibid., s. 8). Hun viser også til at det finnes lite litteratur som problematiserer og samtidig gir nye tanker og verktøy som skoleledere kan anvende i en språklig og kulturelt mangfoldig kontekst. Hun understreker at det er viktig for skoleledere å ha kunnskaper om og forståelse for både sine egne og andres ofte ubevisste verdisett. Spesielt viktig for rektor, hevder hun, er å ha kunnskaper om andrespråksutvikling og hva det innebærer å lære seg et nytt språk.

I Norge ble den nasjonale rektorutdanningen etablert i 2009, i første omgang med tilbud ved 6 universiteter og høyskoler. Vi har kunnskap om den fra en følgeevaluering i perioden 2010-2014 (Hybertsen, Lysø, Stensaker, Solem \& Aamodt, 2013; Hybertsen, Stensaker, Aamodt \& Mjøen, 2011; Hybertsen et al., 2015; Hybertsen, Stensaker et al., 2013). Formålet med evalueringen var å utarbeide kunnskap om hvordan de ulike utdanningstilbudene fungerte i praksis. Evalueringen frembringer informasjon om kvaliteten på selve opplæringstilbudet, deltakernes tilfredshet og deres vurdering av egen utvikling etter endt utdanning. Det sentrale punktet i evalueringen har vært å svare på om utdanningen har bidratt til at den enkelte deltaker blir en bedre leder, og om det var mulig å spore eventuelle endringer på skolene til skoleledernes deltakelse i rektorutdanningen. Rektorutdanningen skal bidra til kompetanseutvikling for deltakerne innen fem hovedkompetanseområder. Det første hovedkompetanseområdet er elevenes læringsprosesser. Det forventes at rektor har tilstrekkelig god fagkompetanse og legitimitet til å gjøre gode faglige vurderinger når det gjelder veiledning og støtte til lærernes arbeid. Det andre hovedkompetanseområdet handler om styring og administrasjon, og forventninger om at rektor kjenner og følger lover og forskrifter. Det tredje knytter seg til samarbeid og organisasjonsbygging, og rektors evne til å bygge et profesjonsfelleskap. Det fjerde området er knyttet til ansvaret for utvikling og endring av skolen, i takt med endringer internt og eksternt, slik at den til enhver tid er tilpasset sine oppgaver og kontekst. Dette for å fange opp endringer i samfunnet, blant annet knyttet til elevgrunnlaget og foresatte. Det femte og siste området understreker forventninger om at ledere fremstår som tydelige, demokratiske, selvstendige og modige.

Målet med det nasjonale rektorprogrammet i Norge var med andre ord ikke eksplisitt knyttet til ledelse i en flerkulturell kontekst, men det er rimelig å hevde at dette inngår som implisitt mål siden opplæringen skal kobles til skolens formålsparagraf og opplæringslov. I den siste av de fire rapportene (Hybertsen et al., 2015) foretas en samlet vurdering av deltakernes opplevelse av rektorutdanningen, hvor de siste tre kullene fra programmet sees under ett. I tillegg rapporteres også resultatene fra deltakere i programmet som ble fulgt til egen 
skole, og hvordan rektorutdanningen har hatt betydning for endringer i praksis på skolene. Sentrale funn i evalueringene viser at deltakernes opplevelse av studieprogrammene var svært positiv, uansett hvilket utdanningstilbud de hadde vært tilknyttet, samt at de opplevde at utdanningens pedagogiske kvalitet og praksisrelevans var høy. Forventninger de hadde om egen utvikling var også innfridd. Det understrekes blant annet at "den nasjonale rektorutdanningen uten tvil har styrket skolelederutdanningen i Norge på ulike måter” (Hybertsen, Stensaker et al., 2013, s. 13). Konkret, basert på deltakernes opplevelse, konkluderer evalueringene med at de som har deltatt i rektorutdanningen har styrket sin kompetanse og fått økt trygghet i sin lederrolle, målt ved økning i egen tro på evnen til å mestre ulike dimensjoner av skolelederrollen. I sluttrapporten (Hybertsen et al., 2015) er analyser fra TALIS-undersøkelsen inkludert, og denne viser at rektorer som har deltatt på en skolelederutdanning synes å prioritere arbeidsoppgaver som i prinsippet støtter opp under elevenes læring.

Evalueringene gir ikke informasjon om hvordan den nasjonale rektorutdanningen har bidratt til, direkte eller indirekte, å gi deltakerne økt lederkompetanse knyttet til sosial rettferdighet, inkludering og likeverd i en språklig og kulturelt mangfoldig kontekst. I denne artikkelen tar jeg utgangspunkt i dette, og undersøker rektorutdanningens potensial til å utvikle ledere for en inkluderende, likeverdig og rettferdig flerkulturell skole.

\section{Teoretisk forankring}

Den teoretiske tilnærmingen er basert på forskning og teorier om skoleledelse som har samme epistemologiske utgangspunkt, nærmere bestemt kritisk teori. Begrepet kritisk teori ble lansert i 1937 av Max Horkheimer, og kan spores til den såkalte Frankfurt-skolen (Kezar \& Carducci, 2007). Den besto av en gruppe forskere på 1930-tallet som var påvirket av marxistisk ideologi. Ideologi var for denne gruppen ansett som dominerende ideer som ble brukt av én klasse til å undertrykke en annen, blant annet gjennom utdanning. I en utdanningskontekst er disse ideene videreutviklet innen kritisk utdanningsforskning (f.eks. Apple, 1996; Freire, 1993; Giroux, 1983, 1994; McLaren, 1995). Et kritisk perspektiv er gjort anvendelig som et analytisk redskap for å identifisere skolers potensial til å utvikle former for kunnskap, verdier og sosiale relasjoner som kan virke frigjørende, fremfor reproduserende for sosioøkonomiske forskjeller og undertrykkelse (Giroux, 1983). Skoler kan for eksempel betraktes som arenaer med et positivt potensial til å skape en motkultur til en nyliberal dreining innenfor europeisk og norsk utdanning (Antikainen, 2006; Karlsen, 2006; Oftedal Telhaug, Mediås \& Aasen, 2006).

Perspektiver utviklet fra kritisk teori reiser spørsmål om utdanningssystemets evne og vilje til å skape like muligheter, snarere enn å reprodusere ulike muligheter (McLaren, 1995; Westrheim, 2004). Innenfor skolelederforskningen 
diskuterer Shields (2010) spenninger mellom kritiske perspektiver og ledelsesteorier som har dominert forskning på skoleledelse de siste tiårene. Hun skiller mellom transformativ ledelse og transformasjonsledelse. Transformasjonsledelse kan beskrives langs åtte dimensjoner: bygge skolens visjon, etablere skolens mål, gi intellektuell stimulering, tilby individuell støtte, modellere beste praksis og viktige organisatoriske verdier, vise høy forventning til ytelse, skape en produktiv skolekultur og utvikle strukturer for å fremme deltakelse i skolens beslutninger (Leithwood, 1994; Leithwood \& Steinbach, 1993). Som utdypet av Leithwood og Jantzi (1999) er transformasjonsledelses fundamentale mål å fremme kapasitetsutvikling og høyere nivåer av personlig forpliktelse til organisatoriske mål. Hver av disse aktivitetene er nødvendige elementer knyttet til skoleledelse, men ikke tilstrekkelige, hevder Shields (2011). Transformativ ledelse fokuserer imidlertid ikke bare på organisasjonsperspektiver, men på de individer og grupper som er mest utsatte og marginaliserte innenfor eksisterende strukturer i skole og samfunn. Shields (ibid.) hevder at transformative ledere begynner, ikke med forpliktelse til organisasjonens mål, men med spørsmål om rettferdighet og demokrati; de kritiserer urettferdig praksis og knytter utdanning og skoleledelse sammen som en uløselig enhet til en større sosial kontekst. Behovet for en tilnærming om ledelse for inkludering ligger også til grunn for Ryans (2006) begrep om inkluderende ledelse. Inkluderende ledelse innebærer vedvarende forpliktelse overfor et mål om å bidra til sosial rettferdighet, og at skolens prosedyrer, prosesser og handlinger bidrar til å utvikle en helhetlig praksis der opplæringen gir alle elever ferdigheter og muligheter til deltakelse i skole og samfunn (Andersen \& Ottesen, 2011). Transformativ ledelse og inkluderingsledelse gir dermed et sett av begreper for å undersøke rektorutdanningens potensial til å utvikle ledere for en rettferdig, inkluderende og likeverdig flerkulturell skole.

Som nevnt presenterer Capper, Theoharis og Sebastian (2006) et rammeverk for å utvikle et skolelederopplæringsprogram som forbereder skoleledere til å utøve en sosial rettferdig ledelse. For å forberede ledere for et sosialt rettferdig samfunn må skolelederprogrammer vektlegge tre kompetanseaspekter. De utgjør en horisontal dimensjon i rammeverket; kritisk bevissthet, kunnskap og praktiske ferdigheter (Capper et al., 2006). Kritisk bevissthet (ibid.), eller det som også noen steder i litteraturen omtales som disposisjoner (Branson, 2007b), er hva ledere tror på, innehar av verdier, og føler seg forpliktet til. Capper et al. (2006) argumenterer for at skoleledere må ha en troverdig bevissthet om sosial rettferdighet som en del av sitt verdisett. Dette innebærer å ha en dyp forståelse for maktrelasjoner og hvordan sosiale konstruksjoner oppstår knyttet til for eksempel majoritetsbefolkningens privilegier (eksempelvis norsk statsborgerskap, norskspråklige ferdigheter og kunnskap om norsk kultur), økonomi, etnosentrisme, heteroseksualitet og kvinneundertrykkelse. Kunnskap om ledelse refererer til hva ledere skal ha kunnskap om og forståelse av (Branson, 2007a). Det sentrale her er hva en leder «vet» (Branson, 2007a, 2007b; Dantley, 
Beachum \& McCray, 2008; Lalas \& Valle, 2007; Mitra, 2004, 2009). Capper et al. (2006) argumenterer for at skoleledere må ha kunnskap om hva forskning peker på som kan skape likeverdige læringsbetingelser for alle elever. Dette innebærer for eksempel kunnskap om andrespråkopplæring. Praktiske ferdigheter referer til aktiviteter og det ledere faktisk kan gjøre (Branson, 2007a, 2007b; Furman \& Shields, 2005). Capper et al. (2006) argumenterer for betydningen av ferdigheter som bidrar til at skoleledere kan omsette bevissthet og kunnskaper i praksis. For eksempel vil det kunne dreie seg om å rekruttere kompetente lærere og rådgivere, og å veilede lærere og tilrettelegge for opplæring for minoritetsspråklige elever.

Innenfor den vertikale dimensjonen refererer Capper et al. (ibid.) til aspekter ved et skolelederopplæringsprogram som kan ha betydning for utvikling av skoleledernes bevissthet, kunnskaper og ferdigheter. Det første aspektet er innholdet (curriculum) i et opplæringsprogram. For eksempel kan dette dreie seg om temaer knyttet til innlæring av norsk som andrespråk, eller rasisme- og antirasisme. Det andre aspektet ved den vertikale dimensjonen dreier seg om pedagogisk tilnærming (pedagogy), som for eksempel kan være undervisningsmetoder, elektroniske plattformsløsninger, erfaringsdeling, valg av arbeidskrav og så videre. Det tredje aspektet er knyttet til evalueringspraksis (assessment), det vil si evaluering av i hvilken grad kritisk bevissthet, kunnskaper og ferdigheter (den horisontale dimensjonen) er utviklet i løpet av studiet. De foreslår at dette kan gjennomføres innenfor programmets rammer på campus, eller der hvor studentene arbeider til daglig.

Formålet med denne studien er å undersøke på hvilken måte rektorutdanningen har potensial til å utvikle ledere for en inkluderende, likeverdig og flerkulturell skole. Perspektiver utviklet fra kritisk teori gir muligheter til å identifisere og diskutere hvordan rektorutdanningen kan bidra til å utvikle skoleledernes kritiske bevissthet, kunnskaper og ferdigheter i en flerkulturell skole. Et kritisk rammeverk gir anledning til å belyse og utfordre normer og ideologier, og å fokusere på praksiser som utvikler former for kunnskap, verdighet og sosiale relasjoner for kritisk myndiggjøring av minoritetsspråklige elever (Giroux, 1983). Et kritisk perspektiv gir altså et sett av begreper som utfordrer normer og ideologier, og som hjelper til med å ha oppmerksomhet mot praksiser som bidrar til reproduksjon av strukturelle forskjeller i utdanningssystemet (Lillejord, 2003; Pihl, 2010). Et kritisk perspektiv er først og fremst opptatt av å fremme rettferdighet og spørsmål knyttet til hva som skaper forbedrede muligheter for marginaliserte grupper (Gorski \& Founder, 2008; Ryan, 2006; Valle, 2006). De aspektene som er viktige innenfor en analyseramme utviklet fra kritisk teori, gir anledning til å diskutere hvordan rektorutdanningen kan bidra til å utvikle skoleledere med mot og handlingsberedskap for å fremme rettferdighet, inkludering og likeverd i skolen. 
For å undersøke rektorutdanningens potensial til å utvikle ledere for en rettferdig, inkluderende og likeverdig flerkulturell skole har jeg valgt et kvalitativt metodisk design innenfor en case-studie.

\section{Design og metode}

Et kjennetegn på en case er at den kan avgrenses i tid og rom, i dette tilfellet skoleledere som har fullført den nasjonale rektorutdanningen i perioden 20132015. Valg av case-studie ga muligheten for en undersøkelse av de ulike rektorutdanningsprogrammene som en kollektiv enhet (Jacobsen, 2015). Det empiriske datamaterialet utgjør i hovedsak notater fra 30 telefonintervjuer med skoleledere i rektorutdanningen.

Rektorutdanningen er tilrettelagt for å kunne kombineres med full jobb som skoleleder. Mine informanter har til felles at alle er i formelle lederstillinger. Intervjuene med de 30 deltakerne ble gjennomført i desember 2015 og januar 2016. Lengden på intervjuene varierte fra 10 til 20 minutter. Dette inkluderer 5 deltakere fra de 6 universitetene og høyskolene som tilbød rektorutdanningen i perioden. Jeg fikk oversikt over deltakernes navn og arbeidssted fra Utdanningsdirektoratet, og tok deretter kontakt med et tilfeldig utvalg skoleledere per telefon. Intervjuguiden var relativt åpen. I første del ba jeg informantene om å reflektere over hvordan innholdet i rektorutdanningen kunne anvendes i arbeidet som leder i en flerkulturell skole. I andre del ba jeg dem om å reflektere over verdier de identifiserte seg med. Jeg intervjuet fem skoleledere fra hvert program. Selv om det utgjør et lite utvalg er det likevel mulig å få reflektert og interessant informasjon ut fra denne studiens formål. Intervjuguidens åpne og relativt enkle spørsmål ga meg samtidig god anledning til å stille kritiske oppfølgingsspørsmål. Et slikt oppfølgingsspørsmål kunne være: I hvilken grad mener du at temaer og problemstillinger knyttet til språklig og kulturelt mangfold er viktige i rektorutdanningen? Som det fremgår av resultatene fører slike oppfølgingsspørsmål til noen kritiske selv-refleksjoner, men også til at noen forsvarer sin innstilling om at det ikke er nødvendig at språklig og kulturelt mangfold behandles som et eget tema. På slutten av intervjuene spurte jeg om det var noe de tenkte jeg ikke hadde spurt om, og om de satt inne med noe de ønsket å formidle.

En begrensning ved datainnsamlingen er knyttet til egne notater og muligheter for tolkningsfeil. For å balansere for tolkningsfeil knyttet til informasjon sendte jeg mine notater fra intervjuet til hver enkelt informant, slik at de fikk anledning til å bekrefte, presisere og endre det jeg hadde skrevet, gjennom såkalt "member-checking" (Postholm, 2010, s. 132). Fire sendte presiseringer og utfyllende svar, som jeg har tatt hensyn til i analysen. Jeg informerte om at de fritt kunne trekke seg fra studien. Det var én deltaker som valgte å trekke seg. 
Telefonintervju ga relativt lett tilgang til skolelederne. Det ga også anledning til en flyt i samtalen, og muligheter for oppfølgingsspørsmål.

Studien følger de etiske retningslinjene fra Personvernombudet for forskning, Norsk samfunnsvitenskapelig datatjeneste AS. Flere forhold ved studien berører etiske forhold. Det første er knyttet til om intervjuet skulle tas opp, for eksempel med en smarttelefon. Siden tidsaspektet ved kontakt per telefon gir begrenset mulighet for å opprette god tillit, valgte jeg å ikke gjøre opptak. Et headset gjorde imidlertid at jeg hadde frie hender og god anledning til å ta gode notater. Det andre etiske aspektet er knyttet til spørsmålet om hensikten med intervjuet skal være skjult eller åpen. Jeg valgte å være tydelig på formålet med undersøkelsen. Jeg var også åpen om at jeg kjente rektorutdanningen godt gjennom mitt arbeid som coach ved rektorutdanningen ved UiO. Et tredje aspekt berører anonymitet. Det mest åpenbare er å sikre deltakernes anonymitet. Mindre åpenbart er kanskje vurderinger knyttet til å anonymisere universitetene/høyskolene? For at intervjupersonene skulle oppleve anonymitet og tillit til at informasjon ble konfidensielt behandlet, har programmene fått pseudonymene A, B, C, D, E, F.

Jeg har valgt en induktiv innholdsanalyse, hvor kategoriseringene springer ut av datamaterialet (Hsieh \& Shannon, 2005), basert på antakelsen om at det var mulig å redusere hele intervjuer til et sett færre og mer overordnede og meningsfylte kategorier (Krippendorf, 2013). Intervjuguiden dannet på forhånd et godt grunnlag for en kategorisering, da spørsmålene var rettet inn mot spesifikke temaer som var gjennomgående for hele undersøkelsen. Intervjuguiden dannet dermed det første settet med kategorier (Jacobsen, 2015). Innholdsanalysene ga rom for en fleksibel tilnærming til tekstdataene (Cavanagh, 1997). Samtidig var innholdsanalyse en velegnet metode for å klassifisere og identifisere mønstre i tekstene (Berg \& Howard, 2012; Hsieh \& Shannon, 2005).

Resultatene fra analysen av intervjuene er organisert i 4 seksjoner. Innledningsvis presenteres resultater fra hva skolelederne oppfatter har vært tatt opp av temaer knyttet til språklig og kulturelt mangfold. De påfølgende seksjonene belyser hva i studiet, og på hvilken måte studiet har bidratt til å øke deres kompetanse.

\section{Resultater}

\section{“Tja, språklig og kulturelt mangfold ...”}

En stor del av skolelederne var veldig tydelige på at temaer som handlet om språklig og kulturelt mangfold, ikke var tatt opp i særlig grad. Dette var ikke uventet, da rektorutdanningen ikke har dette som eksplisitt mål. For eksempel ble spørsmålet diskutert i en basisgruppe ved B: "Vi lette og fant ingen ting. Det var bare en som hadde lest hele pensum, men vi andre hadde lest såpass at vi satt med et overblikk." En skoleleder fra F uttrykte: "Når du sier språklig og kulturelt mangfold, tenker du da fremmedspråklige? Det er et godt spørsmål. 
Det har ikke vært mye i fokus i rektorutdanningen.” En annen reaksjon knyttet til mine spørsmål kan illustreres gjennom et av utsagnene fra E:

Jeg så jo på skjemaet da jeg fikk det. Jeg ble litt satt ut, jeg klarte ikke å svare. Men jeg vil jo komme i den situasjonen, for vi kommer til å ta imot mange her, vi er i prosess på det, men spørsmålene tar meg inn i et ukjent terreng. Jeg tenkte: Dette kan jeg ikke svare på, for det er så ukjent for meg.

Skolelederen kan sies å gi uttrykk for to forhold. Det ene er overraskelsen over spørsmålene i intervjuguiden, og det andre erkjennelsen av usikkerheten knyttet til kompetanse for å håndtere utfordringer som følger av økt andel språklige minoritetselever.

Andre oppfatninger gjenspeiler en spørrende holdning til nødvendigheten av å ha problemstillinger om språklig kulturelt mangfold som et eget tema. For eksempel, en skoleleder fra B kan tolkes i retning av å mene at slike temaer er nyttigere for lærerne enn for skolelederne. Han sier: "Jeg ser at det er utfordringer knyttet til gruppa, men det er mest lærernivået som må håndtere dette.”

Temaer som flere hevder har vært fremtredende i studiet, er personalledelse og elevsentrert ledelse, veiledning og det som handler om å få "folk til å jobbe sammen”. En skoleleder fra B uttrykker at språklig og kulturelt mangfold i skolen ikke har vært noe tema, men at "det har vært et massivt trykk på pedagogisk utviklingsarbeid og organisasjonslæring”.

I neste seksjon beskriver jeg hovedtrekk fra skoleledernes oppfatning om hva i studiet som indirekte kunne tolkes som nyttig for å lede en flerkulturell skole.

\section{"Studiet har i så måte ikke bidratt til min kunnskap om dette emnet"}

Jeg spurte skolelederne om hva i studiet de anså som spesielt nyttig knyttet til en språklig og kulturell kontekst, og hvorfor de eventuelt mente det hadde vært nyttig. En sentral tendens i svarene er at studiet ikke har bidratt til økt kompetanse. Et uttrykk for at studiet ikke hadde bidratt til økt kunnskap knyttet til språklig og kulturelt mangfold, kan vi lese ut fra at en av skolelederne fra D: "Jeg tror ikke jeg har fått økt noe kompetanse, ikke mer enn jeg vet fra før av." På spørsmål om hva han tenker om det, svarer han at "det hadde vært lurt om det var viet en liten plass der". En annen fra samme program (D) omtaler sin kommune som en innlandskommune med økende andel av minoritetsspråklige elever. Hun understreker betydningen av at litteraturen og forelesningene til studiet hadde vært generelt nyttige i forhold til å lede en skole med alle typer elever. Hun legger imidlertid til at "det har allikevel ikke vært spesielt nyttig i forhold til den språklige og kulturelle konteksten vi er i”. To andre, også fra D, har samme oppfatning. Den ene svarer "egentlig i liten grad", og den andre peker på at hun ikke har opplevd at studiet i stor grad har bidratt til å øke kompetansen innen dette området spesielt.

Slike svar er typiske. Fra A uttrykker for eksempel en at “ja, da må jeg tenke meg om. Studiet har først og fremst handlet om organisasjonslæring og peda- 
gogisk ledelse formidlet gjennom forskningsbasert kunnskap”. En annen legger vekt på relasjonell klasseledelse, og om å bli god på å se alle elevene og hva som må til for å oppnå læring. Hun antyder at det ikke nødvendigvis utgjør noen forskjell mellom minoritetsspråklige og majoritetsspråklige elever. "Det er jo det samme for alle. Det med relasjoner til en elev og hva som virker knyttet til læring gjelder også for flerkulturelle klasser og skoler.”

Noen retter også oppmerksomheten mot faren for å definere elever inn i kategorier som minoritetsspråklig og majoritetsspråklig. Ved C mener for eksempel en skoleleder: "Det jeg opplever, også i denne sammenheng, er at for meg er en elev et enkeltindivid uansett. Jeg er derfor litt forsiktig med å definere mennesker inn i ulike 'grupper' og eventuelle diagnoser."

Tilgang på litteratur ble trukket fram som særlig nyttig, her illustrert ved et av utsagnene fra skolelederne på Ds program:

Det er vel ikke et hovedtema som handler om dette, men under emnet om faglig ledelse er det lagt opp et kapittel som omhandler ledelse og språklig og etnisk mangfold. Slike artikler kan jeg anvende inn i min praksis sammen med min egen erfaring og tanker om temaet, kanskje spesielt i forhold til hvordan vi kan tenke på og gjøre bruk av mangfoldet som en ressurs.

Et mønster i svarene er at skolelederne ikke opplever å ha fått økt kompetanse. Det ser også ut til at flere av skolelederne mener det ikke er behov for å ha et spesielt fokus på språklig og kulturelt mangfold, blant annet fordi de da risikerer å dele inn elever etter språklige og kulturelle karakteristikker. Det blir imidlertid også gitt uttrykk for at studiet var nyttig, blant annet gjennom tilgang på relevant litteratur. Kanskje det tydeligste mønsteret knytter seg til at flere skoleledere mener de har fått et generelt stort utbytte av studiet, og peker på at studiet dermed indirekte har gitt dem økt kunnskap om språklig og kulturelt mangfold. Et av utsagnene fra A illustrerer det på denne måten: "Rektorutdanningen har ikke økt kompetansen spesifikt, men mer indirekte.”

\section{"Det må i så fall være indirekte"}

Skolelederen, som sitatet i overskriften er hentet fra, legger til at studiet i stor grad har bidratt til å bevisstgjøre sammenhengen mellom språk og begreper i egen organisasjon, og evnen til å møte utfordringer. Andre peker på at selv om språklig og kulturelt mangfold ikke har vært tatt opp som et eget tema, så har det blitt drøftet i ulike sammenhenger, for eksempel som en del av en problemstilling, uten at det var diskutert eksplisitt. Blant annet svarer en fra A: "Jeg hørte om skoler som hadde store grupper av minoritetsspråklige elever og hvordan de jobbet for å snu skolen for å få bedre resultater, og mer generelt om hvordan man kan heve skolen." Andre har opplevd at de for eksempel har "vært innom det, men under en felles fane knyttet til relasjoner, og der kom det inn". En skoleleder ved B uttrykte noe tilsvarende: "Vi tok det opp i basisgrupper hvor utfordringene ble tematisert innenfor større temaer." Flere understreker at 
studiet har gjort dem tryggere som skoleleder på generell basis. En skoleleder fra C peker på at nettopp det har satt henne "bedre i stand til å ivareta minoriteter i større grad også”. Hun mener at det er noe universelt ved det å være leder, uavhengig av elevsammensetning: "Det handler om å være leder for alle."

Flere oppfatter imidlertid en spesielt nyttig side ved studiet som har direkte relevans knyttet til en språklig og kulturell mangfoldig skolekontekst. Det gjelder den delen av programmet som handler om skolelederes lovanvendelse. For eksempel, som en skoleleder fra $\mathrm{C}$ uttrykker det når det gjelder motivasjon for å starte på studiet: "Mitt utgangspunkt for å ta studiet var å få mer kompetanse på det juridiske feltet. Det å være kompetent på juss, og det å være forberedt på å ta imot elever og familier som har erfaringer fra et annet skolesystem og som har en annen hverdag."

Selv om det ikke er mange skoleledere som trekker frem nytten av temaet om juss, taler uttrykkene i det neste kapittelet for en oppfatning om at studiet har vært nyttig for deres ledelse knyttet til språklig og kulturelt mangfold.

\section{"Det er den juridiske delen jeg har fått med meg mest om, ..."}

Utsagnet fra en skoleleder ved B, som overskriften er hentet fra, refererer til nytten av studiet knyttet til språklig og kulturelt mangfold: "Det er den juridiske delen jeg har fått med meg mest om når det gjelder tilbud til den elevgruppen vi her snakker om.” Til tross for en oppfatning om, slik det er pekt på tidligere, at problematikken knyttet til språklig og kulturelt mangfold ikke er mye vektlagt i rektorutdanningen, er noen av skolelederne allikevel tydelige på nytten knyttet til lovanvendelsen, illustrert ved følgende utsagn fra E:

For å være helt ærlig, så har vi ikke hatt denne problematikken, men det jeg husker er at vi ble presentert for lovverket. Du har blitt mer oppmerksom på rettigheter de har, og at de har krav på ting på lik linje med norske elever. Bevisstgjøringen. Vi har hatt et juss-tema formidlet via en arbeidsrettadvokat. Veldig god forelesning om straffelov, arbeidsmiljøloven og arbeidsavtalen.

Ikke alle svarene er like eksplisitte på sammenhengen mellom lovanvendelse og språklig og kulturelt mangfold, men en av skolelederne fra $\mathrm{C}$ henviser til en del av opplæringsloven som eksplisitt omhandler minoritetsspråklige elever: "Det er viktig å være sikker på, og være tydelige på rettigheter og plikter, særlig paragraf 2.8 om morsmål. Det har ikke vært fokus på morsmålsopplæring i studiet, men det har vært viktig å bli minnet på lovverket.”

\section{Oppsummering}

En stor andel av skolelederne som har vært studenter ved de ulike rektorutdanningsprogrammene, uttrykker at temaer knyttet til språklig og kulturelt mangfold i skolen ikke var berørt i særlig grad. Noen er også opptatt av spørsmål om språklig og kulturelt mangfold utgjør noen forskjell på det å være skoleleder. Flere pekte på at studiet til en viss grad hadde bidratt indirekte til økt 
kompetanse, blant annet ved at temaet språklig og kulturelt mangfold var drøftet i ulike sammenhenger. En liten andel av skolelederne understreker betydningen av å ha kunnskap om anvendelse av lovverket knyttet til språklige minoriteters rettigheter.

I neste seksjon drøfter jeg hvilket potensial rektorutdanningen har til å utvikle ledere for en inkluderende, likeverdig og rettferdig flerkulturell skole.

\section{Rektorutdanningens innholdsside}

\section{Innhold og kritisk bevissthet}

Et gjennomgående og relativt tydelig trekk ved analysen av resultatene viser at rektorutdanningen i liten grad har inneholdt temaer knyttet til språklig og kulturelt mangfold. Dette har heller ikke vært et eksplisitt mål. Skolelederne hevder imidlertid at studiet generelt har bidratt til større bevissthet om sammenhengen mellom språk og utfordringer, og muligheten til å møte utfordringer i en språklig og kulturelt mangfoldig skolekontekst. Spørsmålet er om rektorutdanningen i større grad i fremtiden kan problematisere ledelse i en språklig og kulturelt mangfoldig skolekontekst, og bidra til kritisk bevissthet gjennom forelesninger, litteratur og arbeidskrav som problematiserer og gir rom for å rokke ved vante tenkemåter. Rapp (2002) argumenterer for eksempel for skolelederprogram med et innhold som forplikter ledere til å bekjempe urettferdighet, og som gir muligheter til at de må forlate komfortsonen for å bevege seg inn i mer usikkert farvann, mens Ryan (2006) peker på betydningen av at skoleledere arbeider for en inkluderende skole. Han understreker også betydningen av å utvikle kritisk bevissthet for å identifisere ekskluderende praksiser og rutiner i skolen. Han peker blant annet på at ekskluderende praksiser kan forekomme som en integrert del i det daglige, hektiske arbeidet ved skolen, og at det kan være vanskelig å oppdage dem. Det ligger dermed et ytterligere potensial for rektorutdanningen i å initiere tid og rom for kritiske dialoger som skaper grunnlag for å erkjenne, kritisere og forandre ubevisst praksis som hindrer inkludering og likeverdig opplæring for minoritetsspråklige elever. Analysen i min studie viser at rektorutdanningen har vektlagt utviklingsarbeid, organisasjonslæring og elevenes resultater, uten eksplisitt å ha tatt opp utfordringer knyttet til språklig og kulturelt mangfold. Shields (2010) peker på at det som skiller transformativ ledelse fra transformasjonsledelse, er nettopp å ha et hovedfokus på å avdekke hva som forhindrer likeverdig opplæring, og å identifisere forhold som skaper urettferdige læringsbetingelser for minoritetsspråklige elever. En viktig innholdsside ved rektorutdanningen er å reise spørsmål om i hvilken grad utviklingsarbeidet ved skolen gir lærere rom for at elevmangfoldet kommer til uttrykk og gjøres relevant for alle elever.

Det dreier seg blant annet om å legge opp til at skolelederne skal erkjenne og kritisk reflektere over hvem som har makt til å definere hvilket innhold og 
hvilke perspektiver som er relevante i den pedagogiske praksisen. Et annet poeng er å reflektere over hvordan en slik definisjonsmakt blir reprodusert og kommer til uttrykk. Disse forholdene har ofte nær sammenheng med betingelser knyttet til sosioøkonomiske forhold utenfor skolen (Bakken, 2003; McLaren, 2009) og utgjør dermed et potensial som diskusjonstema for rektorutdanningen når det gjelder å utvikle skolelederes muligheter til å lede en skole i en språklig og kulturelt mangfoldig kontekst.

\section{Innhold og kunnskap}

Resultater fra mine analyser gir få indikasjoner på pensumlitteratur om ledelse i flerkulturelle kontekster. Ved ett av studiestedene (D) ble det imidlertid gitt et eksempel på betydningen av fagspesifikk pensumlitteratur knyttet til språklig og kulturelt mangfold. Det kan for eksempel være hensiktsmessig å koble det flerkulturelle til et spørsmål om likeverd og elevenes rettigheter (Brown, 2004). Selv om analysen viser at fokus på utdanningsrett er noe av det mest konkrete som skolelederne peker på som nyttig i studiet, er det fortsatt andre aspekter som utgjør et stort potensial for rektorutdanningens innholdsdimensjon. Det gjelder for eksempel valg av innhold som utvikler kunnskap om hvordan anvendelse av spesialundervisning kan få negative konsekvenser for minoritetsspråklige elever. Innenfor en norsk kontekst har Pihl (2010) vist hvordan minoritetsspråklige elever har blitt feildiagnostisert, og dermed er overrepresentert i segregert spesialundervisning. Videre er det rimelig å hevde at fokus på antirasistisk arbeid i rektorutdanningen kan bidra til at skoleledere blir bedre på å identifisere og forstå hvordan rasisme fremstår som systematisk undertrykkende (Solomon, 2002). I dette ligger også et potensial for skolelederne til selv å reflektere over sine egne forestillinger og mulige fordommer (ibid.).

Analysen av intervjuene indikerte også en frykt for å skape for skarpe skiller mellom minoritetsspråklige og majoritetsspråklige elever. Det blir for eksempel antydet at det som virker for læring for en majoritetsspråklig elev også gjelder for en minoritetsspråklig, og at det ligger noe universelt i det å være skoleleder, uavhengig av elevsammensetningen, fordi opplæringen må tilpasses den enkelte. Jeg vil imidlertid argumentere for at det ligger et potensial i å velge innhold som bidrar til økt kunnskap om når det er relevant å snakke om forskjeller og likheter mellom minoritetsspråklige elevgrupper og majoritetselever (Lyman \& Villani, 2002). Relevante kunnskapsaspekter i rektorutdanningen som fokuserer på betydningen av forskjeller og likheter kan for eksempel være knyttet til antall år i norsk skole, skoleerfaringer, familiebakgrunn, språkutvikling og deres opprinnelseslands historie. Analysene i mitt materiale viser også at noen av skolelederne stiller spørsmål ved om kunnskap knyttet til språklig og kulturelt mangfold er tilstrekkelig relevant for rektorutdanningen. Dette spørsmålet berører kunnskap om det May (2009) omtaler som fargeblindhet. Han argumenterer for at det ut ifra et kritisk perspektiv er en utfordring hvis forskjellighet gjøres irrelevant, fordi det kan bidra til å usynliggjøre marginaliserte gruppers særskilte 
behov. Likeledes, understreker Pihl (2010), er utfordringen ved å gjøre forskjeller irrelevante at rasistisk praksis kan forekomme uten at den blir definert som sådan. Hun hevder usynliggjøring og fargeblindhet kan føre til en innsnevring av rasismebegrepet, samtidig som rommet for utøvelse av rasisme utvides.

\section{Innhold og ferdigheter}

Foruten det som allerede er nevnt ovenfor når det gjelder lovanvendelse, er det lite i analysen som peker i retningen av at rektorutdanningen har bidratt til at skolelederne oppfatter at de har økt sitt handlingsrepertoar med hensyn til ledelse i en språklig og kulturelt mangfoldig skolekontekst. Flere (f.eks. Andersen \& Ottesen, 2011; Ryan, 2006) peker på betydningen av å fremme inkludering. For at det skal kunne skje, bør rektorutdanningen bidra til å utvikle skoleledere som ikke viker unna for motsetninger, men som oppmuntrer til at ulike meninger får komme til uttrykk (Solomon, 2002). Shields (2010) hevder også at skoleledere trenger ferdigheter $\mathrm{i}$ å lede dialoger som engasjerer personalet i saker som handler om kultur og etnisitet, og som forplikter alle til å undersøke og vurdere sine forestillinger på en slik måte at det skaper initiativ og handling. Sagt på en annen måte, rektorutdanningen har et potensial til å utvikle skoleledere med ferdigheter som "resist, dissent, rebel, subvert oppositional imaginations and are committed to transforming oppressive and exploitative social relations in and out of schools” (Rapp, 2002, s. 226). Det innebærer blant annet at skoleledere utvikler ferdigheter i å ansvarliggjøre og myndiggjøre personalet i sin helhet, gjennom å utvikle prosedyrer og strukturer for medbestemmelse i saker som angår språklig og kulturelt mangfold spesielt (Riester, Pursch \& Skrla, 2002; Theoharis, 2007).

\section{Rektorutdanningens pedagogikk}

\section{Pedagogikk og kritisk bevissthet}

Analysene av datamaterialet viser få indikasjoner på informasjon om og diskusjon rundt undervisningsmetoder som kan øke skoleledernes bevissthet knyttet til maktrelaterte, mangelfulle, likeverdige opplæringsbetingelser for minoritetsspråklige elever.

Imidlertid blir det pekt på at rektorutdanningen ga rom for erfaringsutveksling i basisgrupper om hvordan ulike skoler har håndtert utfordringer ved språklig og kulturelt mangfold. En viktig del av arbeidet som skoleleder er knyttet til ansvaret for utvikling og endring av skolen i takt med samfunnsmessige og skolepolitiske forpliktelser. Potensialet for en pedagogikk med økt fokus på utvikling av økt kritisk bevissthet ligger for eksempel i å innhente minoritetsspråkliges elevers fortellinger om sine "utdanningsreiser", eller informasjon om hvordan de har det på skolen. Det kan dreie seg om å innhente informasjon om deres opplevelser av mestring av skolens fag, og deres rela- 
sjoner til medelever og lærere. Brown (2004) foreslår workshops med fokus på fordommer og rasisme, og å invitere til paneldebatt om aktuelle temaer. Dette kan bidra til økt kritisk refleksjon omkring elevenes læringsbetingelser. For en rektorutdanning er det viktig å utfordre skolelederne på deres praksis, fokusere på å problematisere hvordan kulturelle forestillinger kommer til uttrykk og utgjør en basis for læring og refleksjon i lederteam og i samspillet mellom lærere og ledere. Hvis det er slik at ledelse handler om utøvelse av verdier (Miron, 1996), så gir det mening for rektorutdanningen å utfordre skolelederne til å reflektere kritisk rundt sine egne forestillinger, klargjøre og styrke sine egne verdier, og arbeide for å tilpasse sine aktiviteter og praksis i tråd med sine verdier og perspektiver. Gjennom ulike undervisningsmetoder med dette utgangspunktet ligger det et potensial for å øke skoleledernes handlingsrepertoar og handlingsberedskap for å utøve avgjørende innflytelse, gjennom å engasjere seg i kritisk refleksjon og å bidra til å endre meningsstrukturer i personalet og blant elever og foresatte.

\section{Pedagogikk og kunnskap}

Resultater fra mine analyser viser at skolelederne ikke direkte opplever å ha utviklet kunnskap om ledelse i en flerkulturell og flerspråklig kontekst. Det forventes imidlertid at skoleledere har tilstrekkelig god fagkompetanse og legitimitet til å kunne gjøre gode faglige vurderinger, samt utnytte faglig kompetanse i organisasjonen. Videre skal de kunne ta initiativ til selv å utvikle kunnskap, og de skal kunne legge til rette for utvikling av kunnskap i personalet. Det mest åpenbare potensialet for rektorutdanningen knyttet til denne dimensjonen ligger sannsynligvis i å eksponere studentene for faglitteratur og god praksis. Et eksempel på faglitteratur er aksjonsforskningsstudier, som gir studentene i rektorutdanningen rom til å utvikle ideer og kunnskap om god praksis basert på et samarbeid mellom et forskningsmiljø og et praksisfelleskap ved en skole (Parker \& Shapiro, 1992; Trujillo \& Cooper, 2014). En annen strategi kan være å legge til rette for samarbeidslæring gjennom å følge hverandre på egen skole gjennom en arbeidsdag eller uke, hvor fokus er spesifikt rettet mot utvikling av strategier for en inkluderende, likeverdig og rettferdig flerkulturell skole. Shields (2010) er i tillegg opptatt av å dekonstruere kunnskapsrammer og forestillinger som opprettholder barrierer for inkludering av alle elever. Hun peker på behovet for å konstruere kunnskapsrammer som tar utgangspunkt i elevenes behov for rettferdighet, likeverd og inkludering.

\section{Pedagogikk og ferdigheter}

Analyser av resultatene i denne studien viser at deltakerne mener rektorutdanningen totalt sett har bidratt positivt med hensyn til å ivareta språklige minoriteters rettigheter. Mer spesifikt ligger det imidlertid et stort ubenyttet handlingsrom i å anvende strategier for utvikling av ferdigheter gjennom for eksempel rollespill og å bli utfordret til å svare på kritiske spørsmål fra elever, 
kollegaer eller foreldre og andre samarbeidsaktører (Trujillo \& Cooper, 2014), som for eksempel pedagogisk-psykologisk tjeneste eller oppfølgingstjenesten. Et annet eksempel er å legge opp til skolebesøk som demonstrerer god praksis i et “flerkulturelt klasserom”. Et tredje kan være å la skoleledere ha som et arbeidskrav i studiet å "skygge” en erfaren og dyktig lærer ved egen skole, og skrive refleksjonsnotat i etterkant. En pedagogikk rettet mot å utvikle skoleledernes ferdigheter innenfor et kritisk perspektiv på skoleledelse bærer i seg et potensial til å synliggjøre for studentene hvilke faktorer som gjør at minoritetsspråklige elever ikke har samme muligheter som majoritetsspråklige elever, og kan på den måten bidra til å endre en strukturell urettferdighet (Kincheloe \& Steinberg, 1997). En pedagogikk som tar opp i seg en transformativ og inkluderende tilnærming til ledelse, vil begynne med å drøfte mulige områder av ulikhet der enkelte grupper ikke kan føle seg helt velkommen og inkludert.

\section{Konklusjon}

I denne artikkelen har jeg med basis i litteratur og telefonintervjuer med 30 skoleledere som har fullført rektorutdanningen, drøftet på hvilken måte rektorutdanningen har potensial til å utvikle ledere for en inkluderende, likeverdig og rettferdig flerkulturell skole. Utgangspunktet for studien var at de evalueringene som er gjort av rektorutdanningen i liten grad har berørt dette temaet (Hybertsen et al., 2013). Det er heller ikke formulert som et eksplisitt mål for rektorutdanningen. Som vist i analysen av intervjuene er dette temaet bare indirekte og i liten grad diskutert i utdanningen. Siden spørsmål som berører skolens språklige og kulturelle mangfold har høy aktualitet i dagens samfunn, er mitt hovedargument at dette er viktig å sette på dagsordenen når den nasjonale rektorutdanningen skal videreutvikles. For å sikre en inkluderende, likeverdig og rettferdig opplæring i en språklig og kulturelt mangfoldig skolekontekst har skoleledere et særlig ansvar for å angi retning og utøve innflytelse for å motvirke en praksis preget av feilprioriteringer og forskjellsblinde prinsipper basert på ukritiske argumenter. De kritiske, teoretisk funderte ledelsestilnærmingene har tydelige normative aspekter, basert på verdier knyttet til inkludering, likeverd og rettferdighet. For rektorutdanningen er det nødvendig å innta en eksplisitt, verdibasert posisjon i samsvar med skolens verdigrunnlag når det gjelder kompetanseutvikling for skoleledere i en språklig og kulturelt mangfoldig skole. En klar begrensning i denne studien er at jeg ikke har studert de ulike programtilbydernes emneplaner, hva angår litteraturanbefalinger, lokale målsettinger, prioriteringer av valg av forelesere og temaer, arbeidskrav, eventuelle basisgruppesammensetninger osv. Det er også relativt få informanter fra hver av institusjonene som er spurt om erfaringene med gjennomføringen. Disse begrensningene gir rom for nye problemstillinger og ny kunnskap om 
rektorutdanningens potensial for å utvikle ledere for en inkluderende, likeverdig og rettferdig flerkulturell skole.

\section{Referanser}

Andersen, F. (2012). School leadership and multilingualism. Acta Didactica Norge, 6(1), art. 16.

Andersen, F. \& Ottesen, E. (2011). Skoleledelse og språklig og etnisk mangfold. I J. Møller \& E. Ottesen (red.), Rektor som leder og sjef (s. 250-264). Oslo: Universitetsforlaget.

Antikainen, A. (2006). In search of the Nordic model in education. Scandinavian Journal of Educational Research, 50(3), 229-243. doi: http://dx.doi.org/10.1080/00313830600743258

Apple, M. (1996). Cultural politics and education. New York, NY: Teachers College Press.

Bakken, A. (2003). Minoritetsspråklig ungdom i skolen. Reproduksjon av ulikhet eller sosial mobilitet? (Vol. 15). Oslo: Norsk institutt for forskning om oppvekst, velferd og aldring.

Berg, B. \& Howard, L. (2012). Qualitative research methods for the social sciences. New Jersey: Pearson Education Inc.

Boske, C. (2011). Educating Leaders for Social Justice. I C. Shields (red.), Transformative Leadership. A Reader (s. 362-382). New York, NY: Peter Lang Publishing, Inc.

Branson, C. (2007a). Effects of structured self-reflection on the development of authentic leadership practices among Queensland primary school principals. Educational Management, Administration and Leadership, 35(2), (225-246). doi: http://dx.doi.org/10.1177/1741143207075390

Branson, C. (2007b). Improving leadership by nurturing moral consciousness through structured self-reflection. Journal of Educational Administration, 45(4), 471-495. doi: http://dx.doi.org/10.1108/09578230710762463

Brown, K. M. (2004). Leadership for social justice and equity: Weaving a transformative framework and pedagogy. Educational Administration Quarterly, 40(1), 77-108. doi: http://dx.doi.org/10.1177/0013161X03259147

Bush, T., Kiggundu, E. \& Moorosi, P. (2012). Preparing new principals in South Africa: the ACE: School Leadership Programme. South African Journal of Education, 31, 31-43.

Capper, C., Theoharis, G. \& Sebastian, J. (2006). Toward a framework for preparing leaders for social justice. Journal of Educational Administration, 44(3), 209-224.

Cavanagh, S. (1997). Content analysis: concepts, methods and applications. Nurse Researcher, 4(3), 5-13. doi: http://dx.doi.org/10.7748/nr1997.04.4.3.5.c5869

Dantley, M., Beachum, F. \& McCray, C. (2008). Exploring the intersectionality of multiple centers within notions of social justice. Journal of School Leadership and Policy in Schools, 18, 124-133.

Freire, P. (1993). Pedagogy of the oppressed: New revised 20th-anniversary edition. New York: Continuum.

Furman, G. \& Shields, C. (2005). How can educational leaders promote and support social justice and democratic community in schools? I W. Firestone \& C. Riehl (red.), A new agenda for research in educational leadership (s. 119-137). New York, NY: Teachers College Press.

Giroux, H. (1983). Theory and Resistance in Education: a pedagogy for the opposition. South Hadley, MA: Bergin Press. 
Giroux, H. (1994). Toward a pedagogy of critical thinking. I K. Walters (red.), Re-thinking reason: New perspectives in critical thinking (s. 199-204). Albany: State University of New York Press.

Gorski, P. \& Founder, E. (2008). Good intentions are not enough: a decolonizing intercultural education. Intercultural Education, 19(6), 515-525.

Hsieh, H. \& Shannon, S. (2005). Three approaches to qualitative content analysis. Qualitative Health Research, 5(9), 1277-1288. doi: http://dx.doi.org/10.1177/1049732305276687

Hybertsen, I., Lysø, B., Stensaker, R., Solem, A. \& Aamodt, P. (2013). Ledet til lcering. Nasjonal rektorutdanning i grunn- og videregående skole; deltakernes vurdering av egen utvikling. Delrapport 3 fra Evaluering av den nasjonale rektorutdanningen: Nordisk institutt for studier av innovasjon, forskning og utdanning.

Hybertsen, I., Stensaker, B., Aamodt, P. \& Mjøen, K. (2011). Ledet til ledelse. Nasjonal rektorutdanning i grunn- og videregående skole i et internasjonalt perspektiv. Delrapport 1 fra Evaluering av den nasjonale rektorutdanningen. Oslo: Nordisk institutt for studier av innovasjon, forskning og utdanning.

Hybertsen, I., Stensaker, B., Federici, R., Olsen, M., Solem, A. \& Aamodt, P. (2015). Ledet til endring. Nasjonal rektorutdanning i grunn- og videregående skole; endringer på skolene, måloppnåelse og anbefalinger. Sluttrapport fra Evalueringen av den nasjonale rektorutdanningen. Oslo: Nordisk institutt for studier av innovasjon, forskning og utdanning.

Hybertsen, I., Stensaker, B., Røthe, R., Federici, R., Olsen, M. \& Solem, A. (2013). Ledet til lederutvikling. Nasjonal rektorutdanning i grunn- og videregående skole; forskjeller og likheter mellom de seks programtilbudene. Delrapport 2 fra Evaluering av den nasjonale rektorutdanningen. Oslo: Nordisk institutt for studier av innovasjon, forskning og utdanning.

Jacobsen, D. I. (2015). Hvordan gjennomføre undersøkelser? Innføring i samfunnsvitenskapelig metode. Oslo: Cappelen Damm Akademisk.

Karlsen, G. (2006). Utdanning, styring og marked. Norsk utdanningspolitikk i et internasjonalt perspektiv. Oslo: Universitetsforlaget.

Kezar, A. \& Carducci, R. (2007). Cultivating Revolutionary Educational Leaders: Translating Emerging Theories into Action. Journal of Research on Leadership Education, 2(1), 146. doi: http://dx.doi.org/10.1177/194277510700200104

Kincheloe, J. \& Steinberg, S. (1997). Changing multiculturalism. Philadelphia: Open University Press.

Krippendorf, K. (2013). Content Analysis: An Introduction to Its Methodology (3 ed.). Thousand Oaks, CAL: Sage Publications.

Kunnskapsdepartementet (2004). Stortingsmelding nr 30 (2003-2004) Kultur for læering. Oslo: Statens forvaltningstjeneste.

Kunnskapsdepartementet (2007). Stortingsmelding nr 31 (2007-2008) Kvalitet i skolen. Oslo: Statens forvaltningstjeneste.

Kunnskapsdepartementet (2012). Kompetanse for kvalitet. Strategi for etter- og videreutdanning 2012-2015. Oslo: Kunnskapsdepartementet.

Kunnskapsdepartementet (2016). Meld. St. 28 (2015-2016) Melding til Stortinget Fag Fordypning - Forståelse. En fornyelse av Kunnskapsløftet. Oslo:

Kunnskapsdepartementet.

Lahdenperä, P. (2015). Skolledarskap i mångfald. Lund: Studentlitteratur.

Lalas, J. \& Valle, E. (2007). Social justice lenses and authentic student voices: Enhancing leadership for educational justice. Educational Leadership and Administration, 19, 75102. 
Langfeldt, G., Elstad, E. \& Hopmann, S. (2008). Ansvarlighet i skolen - Politiske spørsmål og pedagogiske svar: resultater fra forskningsprosjektet "Achieving school accountability in practice". Oslo: Cappelen akademisk.

Leithwood, K. (1994). Leadership for school restructuring. Educational Administration Quarterly, 30(4), 498-518.

Leithwood, K. \& Jantzi, D. (1999). Transformational school leadership effects. School Effectiveness and School Improvement, 10(4), 451-479.

Leithwood, K. \& Steinbach, R. (1993). Total quality leadership: Expert thinking plus transformational practice. Journal of Personnel Evaluation in Education, 7(4), 311-337.

Lillejord, S. (2003). Ledelse i en lærende skole. Oslo: Universitetsforlaget.

Lyman, L. \& Villani, C. (2002). The complexity of poverty: a missing component of educational leadership programs. Journal of School Leadership, 12(3), 246-280.

McLaren, P. (1995). Critical Pedagogy and Predatory Culture. New York: Routledge.

McLaren, P. (2009). Critical Pedagogy: A Look at the Major Concepts. I A. Darder, M. Baltodano \& R. Torres (red.), The Critical Pedagogy Reader (s. 61-83). New York: Routledge.

Miron, L. (1996). Resisting discrimination: Affirmative strategies for principals and teachers. Thousand Oaks, CA: Corwin Press.

Mitra, D. (2004). The significance of students: Can increasing "student voice" in schools lead to gains in youth development? Teachers College Record, 106, 651-688.

Mitra, D. (2009). Student voice or empowerment? Examining the role of schoolbased youthadult partnerships as an avenue toward focusing on social justice. I A. Normore (red.), Leadership for social justice: Promoting equity and excellence through inquiry and reflective practice (s. 195-214). Charlotte, NC: Information Age Publishing.

Murphy, J. \& Vriesenga, M. (2004). Research on Preparation Program in Educational Administration: An Analysis. UCEA Monograph Series, University Council for Educational Administration Quarterly. Columbia, MO.

Møller, J. (2004). Lederidentiteter i skolen. Posisjonering, forhandlinger og tilhørighet. Oslo: Universitetsforlaget.

Møller, J. (2009). School leadership in an age of accountability: Tensions between managerial and professional accountability. Journal of Educational Change, 10(1), 37-46.

OECD (2008). Improving School Leadership: Policy and Practice. Paris: Organisation for Economic Cooperation and Development.

Oftedal Telhaug, A., Mediås, O. \& Aasen, P. (2006). The Nordic model in education: Education as part of the political system in the last 50 years. Scandinavian journal of educational research, 50(3), 245-283. doi: http://dx.doi.org/10.1080/00313830600743274

Parker, L. \& Shapiro, J. (1992). Where is the discussion of diversity in educational administration programs? Graduate students' voices addressing an omission in their preparation. Journal of School Leadership, 2, 7-33.

Pihl, J. (2010). Etnisk mangfold i skolen. Det sakkyndige blikket (2. utg.). Oslo: Universitetsforlaget.

Postholm, M. (2010). Kvalitativ metode. En innføring med fokus på fenomenologi, etnografi og kasusstudier. Oslo: Universitetsforlaget.

Rapp, D. (2002). Social justice and the importance of rebellious imaginations. Journal of School Leadership and Policy in Schools, 12(3), 226-245.

Riester, A., Pursch, V. \& Skrla, L. (2002). Principals for social justice: leaders of school success for children from low-income homes. Journal of School Leadership, 12(3), 281304. 
Robinson, V., Lloyd, C. \& Rowe, K. (2008). The impact of leadership on student outcomes: An analysis of the differential effects of leadership types. Educational Administration Quarterly, 44(5), 635-674.

Ryan, J. (2006). Inclusive Leadership. San Francisco: Jossey-Bass. A Wiley Imprint.

Shields, C. (2010). Transformative leadership: Working for equity in diverse contexts. Educational Administration Quarterly, 46(4), 558-589. doi: http://dx.doi.org/10.1177/0013161X10375609

Shields, C. (2011). Transformative Leadership: An Introduction. I C. Shields (red.), Transformative Leadership A Reader (s. 1-19). New York, NY: Peter Lang.

Solomon, R. (2002). School Leaders and Antiracism: Overcoming Pedagogical and Political Obstacles. Journal of School Leadership, 12(2), 174-197.

Theoharis, G. (2007). Social Justice educational leaders and resistance: Toward a theory of social justice leadership. Education Administration Quarterly, 43(2), 221-258. doi: http://dx.doi.org/10.1177/0013161X06293717

Tolo, A. \& Lillejord, S. (2006). Ledelse i en multikulturell skole. Norsk pedagogisk tidsskrift - forum for pedagogikk og fagdidaktikk (2), 120-131.

Trujillo, T. \& Cooper, R. (2014). Framing Social Justice Leadership in a University-Based Preparation Program: The University of California’s Principal Leadership Institute. Journal of Research on Leadership Education, 9(2), 142-167. doi: http://dx.doi.org/10.1177/1942775114525046

Valle, R. (2006). Politisk blikk på skoleledelse. I J. Møller \& O. Fuglestad (red.), Ledelse i anerkjente skoler. Oslo: Universitetsforlaget.

Vedøy, G. (2008). “En elev er en elev”, “barn er barn” og “folk er folk” - Ledelse i flerkulturelle skoler. Oslo: Universitetet i Oslo.

Westrheim, K. (2004). Kritisk pedagogikk og multikulturalisme i lys av Freiretradisjonen. Noen sentrale perspektiv. Nordisk pedagogikk, 3, 212-226. 